Volume 11, Nomor 1, Mei 2019, pp 187 - 198 Copyright (C) 2017 Jurnal Akuntansi Maranatha, Program Studi Akuntansi, Fakultas Ekonomi,Universitas Kristen Maranatha. ISSN 2085-8698 | e-ISSN 2598-4977. http://journal.maranatha.edu

\title{
18 Imperative E-Commerce:Analisis Kesiapan Pelaku UMKM Kota Bandung Dalam Mengembangkan Industri Kreatif Digital
}

\author{
Remon Gunanta \\ Fakultas Ekonomi Program Studi Akuntansi-Universitas Widyatama \\ (Univesitas Widyatama, Jl. Cikutra No. 204 A Bandung 40125) \\ remon.gunanta@widyatama.ac.id \\ Niki Hadian \\ Fakultas Ekonomi Program Studi Akuntansi-Universitas Widyatama \\ (Univesitas Widyatama, Jl. Cikutra No. 204 A Bandung 40125) \\ niki.hadian@widyatama.ac.id
}

\begin{abstract}
Abstrak
Para pelaku UMKM dalam mengahadapi MEA harus memiliki kemampuan menggunakan tekologi informasi, dalam hal ini yaitu e-commerce. Namun pelaku UMKMmemiliki kesiapan yang berbeda. Tujuan dari penelitian ini adalah untuk mengetahui penggunaan teknologi informasi dan sikap pelaku UMKM dalam menerapkan e-commerce.Jenis penelitian adalah penelitian deskriptif sedangkan metode penelitian yang akan digunakan adalah metode kuantitatif dan analisis Multiatribute Attitude Model (MAM). Hasil penelitian menggambarkan bahwa sebagian besar UMKM Kota Bandung memilih menggunakan teknologi informasi dengan media sosial. Sedangkan sikap UMKM Kota Bandung terhadap atribut 18 imperative e-commerce menunjukkan tingkat kesiapan yang baik dalam menerapkan e-commerce.
\end{abstract}

Keywords: e-commerce dan UMKM

\section{Pendahuluan}

Ekonomi digital ditandai dengan semakin maraknya berkembang bisnis dan transaksi perdagangan yang memanfaatkan internet sebagai sarana komunikasi, kolaborasi, dan kooporasi antar perusahaan dengan pelanggan, karyawan, pemasok, dan rekanan logistik ataupun antar individu.Mengacu pada penggunaan teknologi digital dan internet untuk menjalankan proses-proses bisnis utama dalam suatu perusahaan, memunculkan perdagangan elektronik (e-commerce).

E-commerce merupakan bagian dari e-business yang berhubungan dengan kegiatan jual-beli barang/jasa melalui internet.E-commerce juga meliputi aktivitas yang mendukung transaksi tersebut, seperti periklanan, pemasaran, dukungan konsumen, keamanan, pengiriman, dan pembayaran (Laudon, 2015).Semakin meningkatnya komunitas bisnis yang 
mempergunakan internet dalam melakukan aktivitasnya sehari-hari secara tidak langsung telah menciptakan sebuah domain dunia baru yang kerap diistilahkan "cyberspace" atau dunia maya.Berbeda dengan dunia nyata (real word), cyberspace memiliki karakteristik yang untuk dimana seorang manusia dapat dengan mudah berinteraksi dengan siapa saja di dunia ini sejauh yang bersangkutan terhubung ke intenet. Hilangnya batasan dunia yang memungkinkan seseorang berkomunikasi dengan orang lain secara efisien dan efektif ini secara langsung merubah cara perusahaan dalam melakukan bisnis dengan perusahaan lain atau konsumen. (Indrajit, 2016)

Kegiatan bisnis di Indonesia sangat beragam dari jumlah dan jenisnya. Salah satu bentuk usaha yang paling dominan yaitu industri UMKM dengan berbagai karektristik.Sebagian besar berlomba memanfaatkan perkembangan $e$ commerce untuk mempertahankan dan mengembangkan ke arah industri kreatif digital.Namun skala pemanfaatan perkembangan e-commerce belum merata antar individu dan lokasi, karena terkendala faktor sumber daya manusia, pendanaan, dan infrastruktur dan faktor lainnya.

Sumber daya manusia merupakan faktor yang sangat menentukan dalam pemanfaatan e-commerce bagi pelaku usaha UMKM.Pada UMKM yang di Indonesia segala keputusan untuk tumbuh dan berubah menjadi industri kreatif digital ditentukan oleh pemiliknya yang sekaligus pemodal dan pelaku usaha.Perubahan aktivitas manusia di era digital tersebut perlu diimbangi dengan kemampuan sumber daya manusia sebagai pelaku usaha. Kondisi ini sejalan dengan penelitian yang dikemukakan oleh Effendi (2016), dimana potensi utama Indonesia adalah pasar yang sangat besar, masih banyak potensi yang bisa dimanfaatkan oleh industri kreatif digital (IKD), tinggal bagaimana membangun kompetensi dan ekosistem yang mendukung. Dengan karakteristik pasar yang ada di Indonesia, industri $\boldsymbol{e}$ commerceakan terus berinovasi baik darisegi teknologi, logistik, dan aspekaspek penting lainnya dengan dukungan kopetensi sumber daya manusia.

Tantangan pada sumber daya mausia sebagai pelaku UMKM era sekarang dimana telah masuk dalam arena digital, perlu upaya mengembangkan usahanya ke arah industri kreatif digital agar dapat bertahan.Upaya tersebut dapat memberikan gambaran sejauh mana penerapan $e$ commerce yang telah dilakukan selama ini oleh para pelaku UMKM. Melalui analisis dari Peter Fingar, Harsha Kumar dan Tarun Sharma dijelaskan 18 imperative yang mencirikan keberadaan e-commerce dalam dunia bisnis (Fingar, 2000), yaitu: Power Shift to Customer, Global Sales Channel, Reduced Costs of Buying and Selling, Converging Touch Points, Always Open for Business, Reduced Time-to-Market, Enriched Buying Experience, Customization, Self-Service, Reduced Barriers of Market Entry, Demographics of the Internet User, Power Shift to Communities of-Interest, Cybermediation, Logistics and Physical Distribution, Branding: Loyalty and Acceptance Still Have to be Earned, When Most Markets Behave Like the Stock Market, Auctions Everywhere, Hyper-Efficiency.

Sesuai UU Nomor 20 Tahun 2008, kriteria UMKM di Indonesia dapat digolongkan menjadi 3 kelompok berdasarkan jumlah aset dan omset yang dimiliki, dimana kesiapan dan tantangan mengikuti digitalisasi dapat berbeda-beda. Peran para pelaku UMKM memegang kunci untuk memulai atapun meningkatkan penggunaan teknologi informasi dalam menjalankan dan meningkatkan usaha pada era sekarang. Sebagai contoh, UMKM Kota Bandung belum menunjukkan pemanfaatan teknologi infomasi yang merata pada tingkat dan jenis UMKM.

Berdasarkan uraian di atas, penelitian ini bertujuan untuk menganalisis menegeni: 1) Penggunaan teknologi 
informasi olehUMKM Kota Bandung. 2) Tingkat kesiapan UMKM Kota Bandung menerapkan e-commerce. Pada bagian selanjutnya akan dibahas mengenai kerangka teoritis yang berisi konsep dasar. Metode penelitian akan diuraikan pada bagian selanjutnya diikuti dengan hasil penelitian dan pembahasan. Bagian terakhir diuraikan simpulan dan saran bagi penelitian di masa mendatang.

\section{Kerangka Teoritis dan Hipotesis}

\section{Electronic Commerce (E-Commerce)}

Menurut Adi Nugroho (2006:1),electronic commerce (e-commerce) merupakan konsep baru yang biasa digambarkan sebagai proses jual beli barang atau jasa pada world wide web internet atau proses jual beli atau pertukaran produk, jasa dan informasi melalui jaringan informasi termasuk internet. E-commerce merupakan kegiatan bisnis yang dijalankan secara elektronik melalui suatu jaringan internet atau kegiatan jual beli barang atau jasa melalui jalur komunikasi digital. Sedangkan menurut Laudon (2015), e-commerce adalah bagian dari e-business yang berhubungan dengan kegiatan jual-beli barang/jasa melalui internet.E-commerce meliputi aktivitas yang mendukung transaksi tersebut, seperti periklanan, pemasaran, dukungan konsumen, keamanan, pengiriman, dan pembayaran.Sedangkan, menurut Darul Quthni (2006:2), dalam terminologiecommerce yang popular, transaksi yang dialakukan didasarkan pada beberapa jenis yaitu:

1. B2B (Business to Business) yaitu situs web e-commerceyang melakukan kegaiatan bisnis antar pelaku kegiatan bisnis.

2. B2C (Business to Customer) yaitu situs web e-commerce yang melakukan kegiatan bisnis langsung dengan konsumen.
3. $\mathrm{B} 2 \mathrm{G}$ (business to goverment) yaitu situs web e-commerceyang melakukan kegiatan bisnis dengan pemerintah.

4. C2B (customer to business) yaitu konsumen memeritahukan kebutuhan atas suatu produk atau jasa tertentu, dan para pemasok bersaing untuk menyediakan produk atau jasa tersebut ke konsumen.

5. $\mathrm{C} 2 \mathrm{C}$ (customer to customer) yaitu situs web e-commerce yang melakukan kegiatan bisnis antar konsumen. Contoh C2C adalah iklan baris dan toko-toko buku online yang dimiliki oleh individu yang pada umumnya memanfaatkan layanan blog gratis seperti blogspot.

6. Mobile commerce (m-commerce) yaitu transaksi dan aktivitas EC dilakukan dengan teknologi wireless(misal telepon selular)

7. E-learning yaitu penyampaian informasi secara onlineuntuk tujuan pelatihan dan pendidikan

8. Exchange (e-exchange) yaitu pasar elektronik untuk umum yang beranggotakan banyak pembeli dan penjual.

\section{Imperative E-Commerce}

Dalam bukunya "enterprise e-commerce", Peter Fingar, Harsha Kumar dan Tarun Sharma (2000), menjelaskan 18 imperative yang mencirikan keberadaan e-commerce dalam dunia bisnis, yaitu:

1. Power Shift to Customer

Pada era industri terdahulu, filosofi bisnis yang dipergunakan adalah produk sentris, dimana perusahaan menciptakan produk secara masal dan konsumen membelinya.Situasi "satu arah" tersebut disebabkan karena konsumen tidak memiliki informasi yang transparan mengenai biaya penciptaan produk yang ditawarkan, sehingga penjual memiliki kekuatan untuk menentukan harga yang disukainya.Dengan internet, maka terjadilah fenomena "cost transparency" dimana pelanggan 
dapat dengan mudah mengetahui secara gratis informasi dan perkiraan biaya produksi sebuah barang atau jasa.

2. Global Sales Channel

Berbeda dengan berusaha di dunia nyata dimana faktor geografis merupakan arena pertukaran barang atau jasa secara fisikal, arena bisnis $e$ commerce adalah di World Wide Web. Internet memberikan peluang yang sama kepada perusahaan kecil maupun besar, baru maupun lama, dalam hal wilayah jangkauan ke pelanggan. Dengan menghubungkan dirinya ke internet, berarti perusahaan telah terkoneksi dengan seluruh komunitas dunia maya yang ada di bumi ini, tidak perduli seberapa jauh lokasi geografis yang ada. Di sisi lain, perusahaan yang telah mapan akan selalu mendapatkan pesaing baru dari berbagai belahan dunia karena tidak adanya "barrier to entry" dalam memasuki bisnis digital ini.

3. Reduced Costs of Buying and Selling Karakteristik internet secara tidak langsung telah mereduksi biaya variabel hingga mendekati nol.Biaya pencetakan brosur pun dapat dikatakan tidak ada karena secara tidak langsung telah dibebankan kepada pelanggan (mereka yang tertarik cukup mencetak halaman situs terkait). Biaya transaksi pun dapat secara signifikan dikurangi mengingat proses administrasi telah dapat digantikan secara otomatis oleh aplikasi atau perangkat lunak (software). Di sisi pembelian, biaya yang secara signifikan dapat dikurangi adalah biaya penyimpanan barang (inventory cost). Teori Just-In-Time (JIT) atau inventori minimum dapat dengan mudah diterapkan karena aplikasi e-commerce B-to-B (businessto-business) yang menyediakan informasi secara real time dan online dapat diimplementasikan oleh perusahaan dan rekanannya (supplier).
4. Converging Touch Points

Teknologi komputer, elektronika, dan telekomunikasi telah berhasil menciptakan berbagai jenis produkproduk digital mulai dari yang kompleks sampai dengan yang sederhana dan mudah dibawa kemanamana (portable) yang memungkinkan para praktisi bisnis dan pelanggan melakukan transaksi jual beli. Dukungan teknologi telepon genggam (handphone) telah sedemikan berkembang sehingga alat yang tadinya hanya merupakan alat komunikasi, kini telah dapat dipergunakan untuk mencari informasi di internet (browsing) dan melakukan transaksi jual beli saham (teknologi wireless application protocol). Berkembangnyaberbagai jenis produk ini merupakan dampak konvergensi tiga industri: komputer, telekomunikasi, dan informasi (content).

5. Always Open for Business

Bisnis e-commerce merupakan aktivitas 24 jam sehari, 7 hari seminggu, dan 365 hari setahunatau non stop. Representasi sebuah perusahaan dan aktivitasnya di dunia maya adalah situs korporat dengan berbagai fasilitasnya.Transaksi bisnis dimungkinkan dilakukan oleh siapa saja, dari mana saja, dan kapan saja, sehingga tidak ada waktu jeda atau istirahat dalam melayani pelanggan.

6. Reduced Time-to-Market

Beberapa jenis bisnis e-commerce secara tidak langsung telah melibatkan konsumen pada proses produksi sehingga seolah-olah terjadi percepatan pada proses penciptaan produk-produk baru (time-to-market).

7. Enrinched Buying Experience

Berbelanja di internet merupakan pengalaman tersendiri bagi konsumen karena sifatnya yang unik. Tersedianya berbagai jenis perangkat lunak dengan fasilitas yang menarik 
dan menyenangkan dalam menawarkan berbagai cara berbelanja adalah strategi perusahaan $e$ commerce untuk menarik calon pelanggannya di dunia maya. Contohnya adalah diimplementasikannya aplikasi multimedia dalam bisnis pelelangan rumah sehingga seseorang yang tertarik untuk membeli rumah di negara lain dapat dengan mudah melihat keadaan luar dan dalam rumah yang bersangkutan tanpa harus meninggalkan kantor tempatnya bekerja. Keberadaan fasilitas ini tidak saja untuk menarik perhatian pelanggan, namun lebih jauh lagi telah sanggup mengurangi berbagai biaya yang seharusnya terjadi dalam bisnis konvensional.

8. Customization

Salah satu daya pikat dari bisnis $e$ commerce dewasa ini adalah kemampuan yang ditawarkan kepada konsumen untuk menciptakan produk unik sesuai dengan kebutuhan spesifik konsumen tersebut (customization). Produksi secara masal (mass production) secara perlahan-lahan telah bergeser menjadi produk masal yang khusus (mass customization).

9. Self-Service

Berbagai fasilitas (email, chatting, portal, dsb.) di internet secara tidak langsung telah mengajarkan dan memaksa konsumen untuk melayani dirinya sendiri.

10. Reduced Barriers of Market Entry

Konsep "barrier to entry" yang berlaku di dunia nyata hampir tidak dapat diterapkan di dunia maya mengingat begitu mudahnya untuk melakukan bisnis di internet.Mempertahankan keunggulan kompetitifpun merupakan hal yang sangat sulit untuk dilakukan mengingat begitu mudahnya bisnis tertentu ditiru dan dikembangkan.

11. Demographics of the Internet User
Mencermati demografi dari calon konsumen di internet merupakan salah satu kunci keberhasilan usaha, terutama dalam rangka mendefinisikan dan menentukan segmen market yang ingin digarap (khususnya bagi tipe ecommerce B-to-C).Karena telah terjadi pergeseran dari bisnis berbasis produk menjadi bisnis berbasis konsumen, maka perusahaan harus secara jelas memilih target pasarnya.Kebanyakan perusahaan e-commerce yang berhasil, secara kontinyu dan intensif mempelajari dan menganalisa market dan perilaku konsumennya (consumer behavior) berdasarkan data dan informasi yang diperoleh sehari-hari.

12. Power Shift to Communities-ofInterest

Salah satu fenomena yang terjadi di dunia maya adalah kecenderungan pembentukan komunitas-komunitas berdasarkan kepentingan tertentu.Kelompok atau komunitas informal ini secara tidak langsung memiliki peranan yang cukup kuat (bargaining power) karena para konsumen saling memberikan penilaian berdasarkan pengalamannya terhadap mutu atau kualitas produk atau jasa yang ditawarkan perusahaan tertentu.

13. Cybermediation

Keberadaan berbagai komunitas dan sumber informasi secara gratis di internet tentu saja secara tidak langsung akan mematikan berbagai jenis bisnis mediasi seperti yang biasa dilakukan oleh broker, agen, penasehat, distributor, konsultan dan lain sebagainya karena calon konsumen akan cenderung bertanya atau berdiskusi secara gratis dengan komunitasnya di internet. Peranan mereka akan digantikan oleh apa yang dijuluki sebagai "infomediary", yaitu perusahaan yang menguasai informasi. Karena perusahaan inilah yang memiliki informasi sebagai sarana 
penunjang agar barang yang secara fisik diproduksi oleh sebuah perusahaan dapat sampai ke tangan pelanggan secara efisien dan efektif.Infomediary ini pula yang akan berperan besar dalam meningkatkan nilai (value) dari produk atau jasa yang ditawarkan di internet.

14. Logistics and Physical Distribution

Keberhasilan bisnis e-commerce tergantung pada dua variabel besar, yaitu proses logistik (penyimpanan barang secara fisik) dan distribusi (pengiriman barang ke pelanggan). Waktu dan ruang menjadi faktor penentu keberhasilan di sini karena aspek efisiensi,efektivitas, dan kontrol sangat tergantung pada seberapa jauh perusahaan yang bersangkutan memiliki infrastruktur informasi. Konsep JIT (Just-In-Time) inventory hanya dapat dilakukan oleh perusahaan yang memiliki informasi akurat dan infrastruktur jaringan komputer yang baik dengan para supplier. Demikian pula dengan diperlukannya hubungan aliansi melalui komputer dengan perusahaanperusahaan kurir yang bertanggung jawab untuk menyebarkan atau mengirimkan barang ke lokasi tertentu.

\section{Branding Acceptance}

Seperti halnya di dunia nyata, merek tetap dibutuhkan di dunia maya.Alasannya sangat sederhana, karena pada kenyataannya begitu banyak perusahaan-perusahaan yang menawarkan produk atau jasa sejenis, dan calon konsumen harus memilih yang diinginkannya. Aspek-aspek pemasaran seperti TOM (Top of Mind) dan Branding Awareness merupakan target awal yang paling tidak harus diperhitungkan untuk dimiliki oleh sebuah perusahaan di mata pelanggan.

16. Stock Market Behavior

Konsep pasar bebas dan "perfect competition" yang biasa ditemukan dalam teori-teori ekonomi merupakan kenyataan biasa yang terjadi di dunia maya. Transaksi barang dan jasa yang terjadi akan mengikuti pola bursa saham. Harga sebuah barang dan jasa tidaklah tetap, melainkan akan mudah berfluktuasi dari waktu ke waktu karena karakteristiknya yang telah menjadi komoditas. Strategi harga (pricing) yang diimbangi dengan kualitas produk dan pelayanan pelanggan merupakan aspek penentu keberhasilan perusahaan dalam berkompetisi dalam lingkungan dinamis tersebut.

\section{Auctions Everywhere}

Konsep ekonomi "mencari
keuntungan sebanyak-banyaknya
dengan pengorbanan seminimum
mungkin" dimanifestasikan dalama
bentuk model bisnis lelang. Hampir
semua situs-situs besar akan
melakukan teknik penjualan sejenis
lelang dengan berbagai variasinya
terhadap produk atau jasa yang
ditawarkan. Tipe e-commerce B-to-B
dan B-to-C akan segera dilengkapi
dengan jenis transaksi C-to-C.

18. Hyper-Efficiency

Pada akhirnya, target akhir dari dimanfaatkannya internet sebagai medium melakukan transaksi adalah untuk mengifisienkan market. Perusahaan akan berlomba-lomba melakukan efisiensi untuk menekan harga produk atau jasa sehingga secara makro fenomenahyper-efficiency akan terlihat. Yang berhasil memenangkanpersaingan adalah mereka yang dapat melakukan efisiensi tertinggi pada proses bisnisnya (value chain).

\section{Usaha Mikro, Kecil dan Menengah (UMKM)}

Berdasarkan kriteria Usaha Mikro, Kecil Dan Menengah(UMKM) menurut UU Nomor 20 Tahun 2008 digolongkan 
berdasarkan jumlah asset dan omset yang dimiliki oleh sebuah usaha.

\section{Tabel 1}

Kriteria Usaha Mikro, Kecil dan Menengah (UMKM)

\begin{tabular}{|c|c|c|c|}
\hline No & Usaha & Kriteria Aset & Kriteria Omset \\
\hline 1 & $\begin{array}{l}\text { Usaha } \\
\text { Mikro }\end{array}$ & Maks. 50 jt & Maks. $300 \mathrm{jt}$ \\
\hline 2 & $\begin{array}{l}\text { Usaha } \\
\text { Kecil }\end{array}$ & $=50 \mathrm{jt}-500 \mathrm{jt}$ & $\begin{array}{l}>300 \text { jt }-2,5 \\
\text { Miliar }\end{array}$ \\
\hline 3 & $\begin{array}{l}\text { Usaha } \\
\text { Menengah }\end{array}$ & $\begin{array}{l}>500 \mathrm{jt} \\
\text { Miliar }\end{array}$ & $\begin{array}{l}>2,5 \text { Miliar }-50 \\
\text { Miliar }\end{array}$ \\
\hline
\end{tabular}

Sesuai dengan Undang-Undang Nomor 20 Tahun 2008, pengertian Usaha Mikro Kecil dan Menengah (UMKM) adalah:

1. Usaha mikro adalah usaha produktif milik orang perorangan dan/atau badan usaha perorangan yang memenuhi kriteria usaha mikro sebagaimana diatur dalam undangundang ini.

2. Usaha kecil adalah usaha ekonomi produktif yang berdiri sendiri, yang dilakukan oleh orang perorangan atau badan usaha yang bukan merupakan anak perusahaan atau bukan cabang perusahaan yang dimiliki, dikuasai, atau menjadi bagian baik langsung maupun tidak langsung dari usaha menengah atau usaha besar yang memenuhi kriteria usaha kecil sebagaimana dimaksud dalam undangundang ini.

3. Yang dimaksud usaha kecil dan menengah adalah kegiatan usaha dengan skala aktivitas yang tidak terlalu besar, manajaemen masih sangat sederhana, modal yang tersedia terbatas, pasar yang dijangkau juga belum luas.

4. Usaha menengah adalah usaha ekonomi produktif yang berdiri sendiri, yang dilakukan oleh orang perseorangan atau badan usaha yang bukan merupakan anak perusahaan atau cabang perusahaan yang dimiliki, dikuasai, atau menjadi bagian baik langsung maupun tidak langsung dengan usaha kecil atau usaha besar dengan jumlah kekayaan bersih atau hasil penjualan tahunan sebagaimana diatur dalam undang-undang ini.

\section{Metode Penelitian}

\section{Metode Penelitian}

Jenis penelitian yang digunakan adalah penelitian deskriptif sedangkan metode penelitian yang akan digunakan adalah metode kuantitatif dan analisis Multiatribute Attitude Model (MAM). Pendekatan diskriptif kuantitatif adalah teknik mengumpulkan, mengelola, menyederhanakan, menyajikan dan menganalisis data sekunder agar dapat memberikan gambaran yang teratur tentang suatu peristiwa dengan observasi yang dapat dinyatakan angka-angka.Sedangkan analisis MAM digunakan untuk membandingkan antara kepentingan dan penerapan atribut 18 imperative $e$ commerce. Pembahasan akan mengacu pada hasil observasi lapangan yaitu survey dimana informasi yang diperoleh dari responden dengan menggunakan kuesioner, skala likert.

\section{Objek Penelitian}

Objek dari penelitian ini adalah UMKM di kota Bandung Jawa Barat. Subyek penelitian ini adalah UMKM di Kota Bandung yang telah menggunakan teknologi informasi. Tempat penelitian adalah di kota Bandung.

\section{Populasi dan Sampel}

Populasi dalam penelitian ini adalah UMKM Kota Bandung yang telah menggunakan teknologi informasi, dengan jumlah 137.Mengingat jumlah populasi cukup banyak, maka dalam rangka efisiensi dan keefektifan penelitian, dilakukan sampling (pengambilan sampel).Berdasarkan prosesnya, sampel yang digunakan dalam penelitian ini adalah 
dengan menggunakan metode accidental sampling.Menurut Sugiyono (2008) accidental sampling merupakan teknik penentuan sampel secara kebetulan, yaitu siapa saja yang secara kebetulan bertemu dengan peneliti, dan orang tersebut dipandang cocok sebagai sumber data.Dalam penelitian ini sampel yang diambil sebanyak 35 UMKM.Sampel dalam penelitian ini adalah UMKM, dikarenakan UMKM juga merupakan bentuk usaha serta memiliki peluang untuk menerapkan $e$ commerce.

\section{Data Penelitian}

Sumber data dalam penelitian ini diperoleh dari data primer dan data sekunder. Pada penelitian ini data primer langsung didapatkan dari responden, dengan cara memberikan kuesioner serta wawancara yang dilakukan sendiri oleh peneliti dari responden. Sumber data lebih ditekankan pada UMKM yang telah menggunakan teknologi informasi dalam menjalankan usanya.Sedangkan data sekunder didapatkan dari observasi yaitu melakukan pengamatan secara langsung ke objek penelitian untuk melihat dari dekat kegiatan yang dilakukan. Selain itu data sekunder diperoleh melalui library research yang merupakan pengumpulan data dengan mempelajari dasar teori dari buku-buku ekonomi, dan mengambil literatur-literatur seperti: buku, artikel, jurnal, dan sejenisnya yang berhubungan dengan apa yang diteliti oleh peneliti.

\section{Metode Analisa Data}

\section{Teknik Analisis Data}

Dalam menganalisis data penulis menggunakan teknik analisis data, yaitu dengan cara:

1. Menganalisis secara deskriptif mengenai teknologi informasi yang digunakan oleh UMKM di Kota Bandung dalam menjalankan usahanya. Dilakukan dengan melihat preferensi dari responden dan mengolompokkan data untuk digambarkan dalam bentuk presentase.

2. Menganalisis dan menilaisikapUMKM Kota Bandung terhadap 18 imperative ecommerce. Data yang diperoleh melalui kuesioner akan dianalisis dengan menggunakan analisis Multiattribute Attitude Model (MAM). Analisis MAM ini digunakan untuk menilai sikap responden secara keseluruhan terhadap perspektif penerapan 18 Imperative $E$ Commerce. Analisis ini menggunakan rumus sebagai berikut:

$$
A b=\sum_{i=1}^{n} W i|I i-X i|
$$

Keterangan:

$\mathrm{Ab}=$ Sikap seseorang secara keseluruhan terhadap suatu objek

$\mathrm{Wi}=$ Bobot rata-rata yang diberikan responden terhadap atribut $\mathrm{i}$

$\mathrm{Li}=$ Nilai ideal rata-rata konsumen pada atribut $\mathrm{i}$

$\mathrm{Xi}=$ Nilai belief rata-rata konsumen pada atribut $\mathrm{i}$

$\mathrm{n}=$ Jumlah atribut

Rumus di atas diperoleh dengan menggunakan langkah-langkah perhitungan sebagai berikut:

a. Menentukan Wi dengan rumus:

$$
\text { Wi }=\frac{\text { nilai } m a \sin g-m a \sin g \text { atribut }}{\text { nilai atribut }} \times 100 \%
$$

b. Menentukan skala sikap dalam bentuk skor dengan angka 1 sampai dengan 5, urutannya sebagai berikut: 


\section{Tabel 2}

\begin{tabular}{|c|c|c|}
\hline No. & Jawaban & $\begin{array}{l}\text { Skor } \\
\text { Sikap }\end{array}$ \\
\hline 1 & Sangat & 5 \\
\hline & $\begin{array}{l}\text { Penting } \\
\text { atau } \\
\text { Sudah } \\
\text { Dilakukan }\end{array}$ & \\
\hline 2 & $\begin{array}{c}\text { Penting } \\
\text { atau } \\
\text { Sering }\end{array}$ & 4 \\
\hline 3 & $\begin{array}{l}\text { Ragu- } \\
\text { ragu atau } \\
\text { Kadang- } \\
\text { kadang }\end{array}$ & 3 \\
\hline 4 & $\begin{array}{l}\text { Kurang } \\
\text { Penting } \\
\text { atau } \\
\text { Jarang } \\
\text { Dilakukan }\end{array}$ & 2 \\
\hline 5 & $\begin{array}{l}\text { Tidak } \\
\text { Penting } \\
\text { atau } \\
\text { Tidak } \\
\text { Dilakukan }\end{array}$ & 1 \\
\hline
\end{tabular}

c. Mencari nilai ideal dan nilai belief, digunakan rumus sebagai berikut:

Nilai ideal $=$ skor $\mathrm{x}$ absolut responden ideal masing- masing alternatif jawaban

Nilai belief $=$ skor $\mathrm{x}$ absolut responden belief masing-masing alternatif jawaban

Mencari nilai ideal rata-rata dan nilai belief rata-rata menggunakan rumus sebagai berikut:

Nilai ideal rata - rata $=\frac{\text { total nilai ideal }}{\text { responden ideal }}$

Nilai belief rata - rata $=\frac{\text { total } \text { nilaibelief }}{\text { responden belief }}$

d. Memasukkan hasil perhitungan dengan analisis $M A M$ ke dalam skala likert,yang dapat digambarkan sebagai berikut:

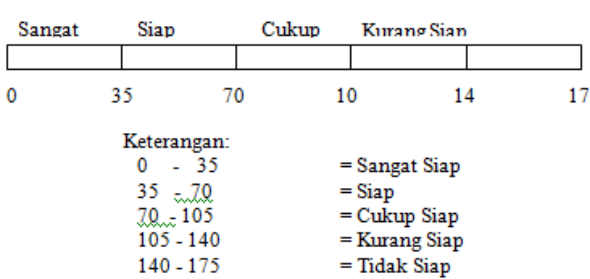

Hasil perhitungan skala sikap secara keseluruhan dapat diartikan jika skala semakin ke kiri atau mendekati nol, maka responden merasa semakin puas.Hal tersebut menunjukkan rentang yang semakin kecil antara penerapan $e$ commerceyang diharapkan dengan penerapane-commerceyang sesungguhnya. Sehingga rentang yang semakin kecil antara penerapan harapan dengan penerapan yang sesungguhnya berarti menunjukkan kinerja yang semakin siap pada perspektif tersebut. Hal tersebut akan berlaku sebaliknya.

\section{Hasil Penelitian dan Pembahasan}

\section{Deskripsi Data Penelitian}

Pada analisis deskriptif dalam penelitian ini menjelaskan gambaran data-data UMKM Kota Bandung yang berupa: jumlah, jenis, lama berdiri, dan omset usaha. Analisis dilakukan dengan memberikan gambaran mengenai jumlah dan jenis usaha dikaitkan dengan penggunaan teknologi informasi (TI) dalam bentuk tabel yang diolah melalui analisis statistik.

\section{Jumlah dan Jenis UMKM Kota Bandung yang menggunakan TI}

Analisis deskriptif berikut ini untuk menggambarkan penggolongan jenis UMKM Kota Bandung dalam menggunakan teknologi informasi (TI). 
Tabel 3

Jumlah dan Jenis UMKM yang Menggunakan TI

\begin{tabular}{|c|c|c|c|c|c|c|c|}
\hline No Klasifilkasi & Fashion & Foods & $\begin{array}{l}\text { Handy } \\
\text { craft }\end{array}$ & Jasa & Perdagangan & Total & $\%$ \\
\hline 1 MenggumakanIT & 23 & 73 & 22 & 15 & 4 & 137 & 33 \\
\hline 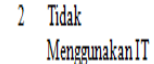 & 45 & 147 & 22 & 34 & 36 & 284 & 67 \\
\hline Iotal & 68 & 220 & 44 & 49 & 40 & 421 & 100 \\
\hline
\end{tabular}

Sumber data: Data Dinas Koperasi dan

UMKM Kota Bandung yang diolah

\begin{abstract}
Analisis Pola Pelaku UMKM Kota Bandung dalam Menggunakan Teknologi Informasi $E$-Commerce.

Pelaku UMKM Kota Bandung dalam menggunakan teknologi informasi diklasifikasikan berdasarkan pola pelaku UMKM dalam menggunakan media ecommercedalam bentuk media sosial, web enterprice, dan penyedia layanan. Hal tersebut dapat dijabarkan sebagai berikut:
\end{abstract}

Tabel 4

Jenis Media e-commerce

\begin{tabular}{|c|c|c|c|c|c|c|c|}
\hline $\begin{array}{ll}\text { No } & \text { Mlasiflkasi }\end{array}$ & Fashion & Foods & Handycraft & Jasa & Perdagangan & Iotal & $\%$ \\
\hline \multirow{3}{*}{$\begin{array}{ll}1 & \text { Media Sosial } \\
2 & \text { Web Enterpice } \\
3 & \text { Penvedia Layanan } \\
\text { Web }\end{array}$} & 13 & 39 & 8 & 6 & 2 & 68 & 50 \\
\hline & $j$ & 13 & 1 & $j$ & 1 & 31 & \\
\hline & s & 21 & 1 & 4 & 1 & 38 & \\
\hline Iotal & 23 & 73 & 22 & 15 & 4 & & \\
\hline
\end{tabular}

Sumber data: Data Dinas Koperasi dan UMKM Kota Bandung

Tingkat kesiapan UMKM menerapkan $e$ commerce diukur dengan 18 imperative ecommerce.

Sikap kesiapan UMKM kota Bandung terhadap penerapan atribut-atribut $e$ commercedilakukan terbatas pada sempel penelitian dan dengan menggunakan metode Multiatribute Attitude Model (MAM) dengan langkah-langkah sebagai berikut:

a. Menentukan bobot dan urutan kepentingan.
Urutan kepentingan yang diberikan oleh pelaku UMKM Kota Bandung terhadap masing-masing atribut, dilakukan dengan menghitung selisih antara urutan kepentingan yang satu dengan yang lain dengan jumlah total bobot 35 .

Tabel 5

Tingkat Bobot (Wi)

\begin{tabular}{ccc}
\hline No & Tingkat Kepentingan & Bobot \\
\hline 1 & $18 / 71 \times 35$ & 3,68 \\
2 & $17 / 24 \times 35$ & 3,48 \\
3 & $16 / 24 \times 35$ & 3,27 \\
4 & $15 / 24 \times 35$ & 3,07 \\
5 & $14 / 24 \times 35$ & 2,87 \\
6 & $13 / 24 \times 35$ & 2,66 \\
7 & $12 / 24 \times 35$ & 2,46 \\
8 & $11 / 24 \times 35$ & 2,25 \\
9 & $10 / 24 \times 35$ & 2,05 \\
10 & $9 / 24 \times 35$ & 1,84 \\
11 & $8 / 24 \times 35$ & 1,64 \\
12 & $7 / 24 \times 35$ & 1,43 \\
13 & $6 / 24 \times 35$ & 1,23 \\
14 & $5 / 24 \times 35$ & 1,02 \\
15 & $4 / 24 \times 35$ & 0,82 \\
16 & $3 / 24 \times 35$ & 0,61 \\
17 & $2 / 24 \times 35$ & 0,41 \\
18 & $1 / 24 \times 35$ & 0,20 \\
171 & & $\mathbf{3 5 , 0 0}$ \\
\hline
\end{tabular}

Dari tabel 5 dapat dilihat pemberian bobot (Wi) bagi masing-masing atribut berdasarkan urutan kepentingan, dengan menjumlahkan urutannya sebagai berikut:

$1+2+3+4+5+6+7+8+9+10+11+12+13+$ $14+15+16+17+18=171$ dengan jumlah bobot 35 dan besarnya bobot masingmasing urutan tingkat kepentingannya.

b. Menghitung ideal dan belief rata-rata dan selisihnya.

Ideal (Ii) diperoleh dari harapan atau keinginan UMKM terhadap atributatribut keberadaan imperative ecommerce, sedangkan belief (Xib) diperoleh dari pendapat atau kondisi yang dipercaya UMKM terhadap atribut-atribut penerapan imperative $e$ commerce. Perhitungan ideal dan belief rata-rata dan selisihnya dapat dilihat pada tabel di bawah ini. 
Tabel 6

Perhitungan Ideal dan Belief Rata-rata dan Selisihnya

\begin{tabular}{|c|c|c|c|c|c|c|c|c|c|c|c|c|c|c|}
\hline \multirow[b]{2}{*}{ Sikap Pemilik LXIKM } & \multicolumn{5}{|c|}{ Ideal } & \multicolumn{6}{|c|}{ Belief } & \multirow[b]{2}{*}{ Total } & \multirow{2}{*}{$\begin{array}{l}\text { Seli- } \\
\text { sih }\end{array}$} & \multirow{2}{*}{$\begin{array}{c}\text { Crutan } \\
\text { Kepent- } \\
\text { ngan } \\
\end{array}$} \\
\hline & 5 & 4 & 3 & 21 & & Total & 5 & 4 & 3 & 2 & 1 & & & \\
\hline 1.Power shiff to costumer & & & & & & & & & & & & & & \\
\hline $\begin{array}{l}\text { Jumlah } \\
\text { Absolut }\end{array}$ & $\begin{array}{c}55 \\
275\end{array}$ & 29 & 17 & 40 & & $\begin{array}{l}105 \\
450\end{array}$ & 40 & 41 & 17 & 7 & 0 & $\begin{array}{l}105 \\
429\end{array}$ & & \\
\hline $\begin{array}{l}\text { Absolut } \\
\text { Rata-Rata } \\
\text { 2.Global Seles Channel }\end{array}$ & & & & & & 4.29 & & & 31 & 14 & & 4.09 & 0.20 & 13 \\
\hline Jumlah & 31 & 27 & 8 & 22 & 2 & 70 & 34 & 13 & 12 & 4 & 7 & 70 & & \\
\hline Absolut & 155 & 108 & 24 & 42 & 2 & 293 & 170 & 52 & 36 & 8 & 7 & 273 & & \\
\hline $\begin{array}{l}\text { Rata-Rata } \\
\text { 3.Reduced cost of buying and } \\
\text { selling }\end{array}$ & & & & & & 4.19 & & & & & & 390 & 0.29 & 11 \\
\hline Jumlah & 22 & 29 & 8 & 65 & 5 & 70 & 21 & 16 & 12 & 14 & 7 & 70 & & \\
\hline Absolut & 110 & 116 & 24 & 12 & & 267 & 105 & 64 & 36 & 28 & 7 & 240 & & \\
\hline $\begin{array}{l}\text { Rata-Rata } \\
\text { 4.Conserging Touch Points }\end{array}$ & & & & & & 3.81 & & & & & & 3.43 & 0.39 & 6 \\
\hline Jumlah & 8 & 10 & 8 & 63 & 3 & 35 & 4 & 4 & 15 & 6 & 6 & 35 & & \\
\hline Absolut & 40 & 40 & 24 & 123 & 3 & 119 & 20 & 16 & 45 & 12 & 6 & 99 & & \\
\hline $\begin{array}{l}\text { Rata-Rata } \\
\text { 5.Abrays open for business }\end{array}$ & & & & & & 3.4 & & & & & & 283 & 0.57 & 2 \\
\hline Jumlah & 7 & 7 & 15 & 24 & 4 & 35 & 5 & 9 & 6 & 3 & 12 & 35 & & \\
\hline Absolut & 35 & 28 & 45 & 4. & 4 & 116 & 25 & 36 & 18 & 6 & 12 & 97 & & \\
\hline $\begin{array}{l}\text { Rata-Rata } \\
\text { 6.Reduced time to market }\end{array}$ & & & & & & 331 & & & & & & $2.77 \mathrm{~d}$ & 0.54 & 3 \\
\hline Jumlah & 11 & 14 & 8 & 02 & 2 & 35 & 12 & 8 & 8 & 3 & 4 & 35 & & \\
\hline Absolut & 55 & 56 & 24 & 02 & 2 & 137 & 60 & 32 & 24 & 6 & 4 & 126 & & \\
\hline $\begin{array}{l}\text { Rata-Rata } \\
\text { 7.Envinched buyjug experience }\end{array}$ & & & & & & 391 & & & & & & 3.600 & 0.31 & 10 \\
\hline Jumlah & 10 & 14 & 7 & 1 & 3 & 35 & 5 & 9 & 6 & 6 & 9 & & 35 & \\
\hline Absolut & 50 & 56 & 21 & 2 & 3 & 132 & 25 & 36 & 18 & 812 & 29 & 100 & 00 & \\
\hline $\begin{array}{l}\text { Rata-Rata } \\
\text { 8. Costumization }\end{array}$ & & & & & & 3.77 & & & & & & 2.86 & 86091 & 1 \\
\hline Jumlah & 26 & 19 & 20 & 0 & 5 & 70 & 12 & 27 & 14 & 49 & 98 & 70 & 70 & \\
\hline Absolut & 130 & 76 & 60 & 0 & 5 & 271 & 60 & 108 & 842 & 218 & 88 & 236 & 36 & \\
\hline $\begin{array}{l}\text { Rata-Rata } \\
9 . \text { Self senice }\end{array}$ & & & & & & 3.87 & & & & & & 3.37 & 370.50 & 4 \\
\hline Jumlah & 14 & 14 & 6 & 0 & 1 & 35 & 11 & 12 & 9 & 0 & & 35 & 35 & \\
\hline Absolut & 70 & 56 & 18 & 0 & 1 & 145 & 55 & 48 & 27 & 70 & 3 & 133 & 33 & \\
\hline $\begin{array}{l}\text { Rata-Rata } \\
\text { 10.Reduced Burriers of Market } \\
\text { Entry }\end{array}$ & & & & & & 4.14 & & & & & & 3.80 & $80 \quad 0.34$ & 8 \\
\hline Jumlah & 21 & 30 & 13 & 3 & 3 & 70 & 18 & 20 & 25 & 53 & 34 & 70 & 70 & \\
\hline Absolut & 105 & 120 & 39 & 6 & 3 & 273 & 90 & 80 & 75 & 56 & 64 & 255 & 55 & \\
\hline $\begin{array}{l}\text { Rata-Rata } \\
\text { 11.Demographics of the Intemet } \\
\text { Cser }\end{array}$ & & & & & & 3.9 & & & & & & 3.64 & 640.26 & 12 \\
\hline Jumlah & 9 & 18 & 8 & 0 & 0 & 35 & 8 & 13 & 1. & 40 & 0 & 35 & 35 & \\
\hline Absolut & 45 & 72 & 24 & 0 & 0 & 141 & 40 & 52 & 42 & 20 & 0 & 134 & 34 & \\
\hline $\begin{array}{l}\text { Rata-Rata } \\
\text { 12.Power Shiff to Comomunities of } \\
\text { Interest }\end{array}$ & & & & & & 4.03 & & & & & & 3.83 & $83 \quad 0.20$ & 15 \\
\hline Jumlah & 12 & 9 & 8 & 1 & 5 & 35 & 9 & 12 & 27 & 5 & 52 & 35 & 35 & \\
\hline Absolut & 60 & 36 & 24 & 2 & 5 & 127 & 45 & 48 & 321 & 110 & 02 & 126 & 26 & \\
\hline Rata-Rata & & & & & & 3.63 & & & & & & 3.60 & $60 \quad 0.03$ & 16 \\
\hline 13. Ç̣bemediation & & & & & & & & & & & & & & \\
\hline Jumlah & 6 & 17 & 9 & 30 & 0 & 35 & 6 & 5 & 19 & 3 & 2 & 35 & & \\
\hline Absolut & 30 & 682 & 27 & 60 & 0 & 131 & 30 & 20 & 57 & 6 & 2 & 115 & & \\
\hline $\begin{array}{l}\text { Rata-Rata } \\
\text { 14. Logisticsand Physical } \\
\text { Distribution }\end{array}$ & & & & & & 3.74 & & & & & & 3290 & 0.46 & 5 \\
\hline Jumlah & 16 & 10 & 7 & 20 & & 35 & 18 & 5 & 6 & 4 & 2 & 35 & & \\
\hline Absolut & 80 & 402 & 21 & 40 & 0 & 145 & 90 & 20 & 18 & 8 & 2 & 138 & & \\
\hline $\begin{array}{l}\text { Rata-Rata } \\
\text { 15.Brunding Acceptonce }\end{array}$ & & & & & & 4.14 & & & & & & 3940 & 0.20 & 14 \\
\hline Jumlah & 10 & 17 & 8 & 0 & 0 & 35 & 12 & 13 & 10 & 0 & 0 & 35 & & \\
\hline Absolut & 50 & 68 & 24 & 00 & 0 & 142 & 60 & 52 & 30 & 0 & 0 & 142 & & \\
\hline $\begin{array}{l}\text { Rata-Rata } \\
\text { 16. Stock Market Beharior }\end{array}$ & & & & & & 4.06 & & & & & & 4.06 & 0 & 18 \\
\hline Jumlah & 15 & 14 & 6 & 0 & 0 & 35 & 18 & 9 & 7 & 1 & 0 & 35 & & \\
\hline Absoht & 75 & 56 & 18 & 0 & 0 & 149 & 90 & 36 & 21 & 2 & 0 & 149 & & \\
\hline $\begin{array}{l}\text { Rata-Rata } \\
\text { 17.Auctions Everywhere }\end{array}$ & & & & & & 4.26 & & & & & & 426 & 0 & 17 \\
\hline Jumlah & 11 & 8 & 6 & 6 & 4 & 35 & 7 & 7 & 12 & 1 & 8 & 35 & & \\
\hline Absolut & 55 & 32 & 18 & $12+$ & 4 & 121 & 35 & 28 & 36 & 2 & 8 & 109 & & \\
\hline $\begin{array}{l}\text { Rata-Rata } \\
\text { 18.Hpper-Efficiency }\end{array}$ & & & & & & 3.46 & & & & & & 3.11 & 0.34 & 9 \\
\hline Jumlah & 16 & 12 & 7 & 0 & 0 & 35 & 14 & 8 & 9 & 4 & 0 & 35 & & \\
\hline Absolut & 80 & 48 & 21 & 0 & 0 & 149 & 70 & 32 & 27 & 8 & 0 & 137 & & \\
\hline Rata-Rata & & & & & & 426 & & & & & & 391 & 0.34 & 7 \\
\hline
\end{tabular}

Dari perhitungan di atas maka dapat dinilai sikap UMKM sebagai berikut:

$$
\begin{aligned}
\mathrm{Ab}= & 3,68(3,77-2,86)+3,48 \quad(3,4- \\
& 2,83)+3,27(3,31-2,77)+3,07 \\
& (3,87-3,37)+2,87(3,74-3,29)+ \\
& 2,66(3,81-3,43)+2,46 \quad(4,26- \\
& 3,91)+2,25(4,14-3,80)+2,05 \\
& (3,46-3,11)+1,84(3,91-3,60)+ \\
& 1,64(4,19-3,90)+1,43(3,9- \\
& 3,64)+1,23(4,29-4,09)+1,02 \\
& (4,14-3,94)+0,82(4,03-3,83)+ \\
& 0,61(3,63-3,60)+0,41 \quad(4,26- \\
& 4,26)+0,20(4,06-4,06) \\
= & 15,37
\end{aligned}
$$

Dengan skala interval dapat dilihat seperti pada gambar berikut ini:

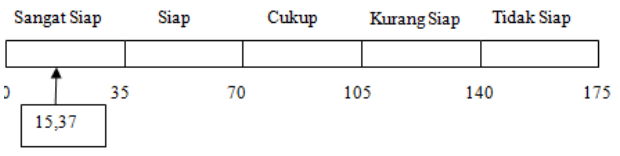

Tanggapan pelaku UMKM Kota Bandung terhadap atribut-atribut penerapan imperative-commerce jika digolongkan ke dalam skala interval akan masuk dalam kelompok nilai pada rantang $0-35$ dan masuk dalam kategori sangat siap.

Berdasarkan perhitungan nilai sikap dengan menggunakan Multiatribut Attitude Model (MAM), maka pelaku UMKM Kota Bandung memiliki kesiapan yang sangat baik dalam menerapkan e-commerce. Hal tersebut didukung dengan tanggapan responden pada atribut branding acceptance dan stock market behavior yang telah sesuai harapan.Diterapkannya branding acceptence dengan baik menunjukkan bahwa UMKM Kota Bandung telah memperhatikan pada penilaian merek dagang, mengingat banyak produk atau jasa sejenis dan konsumen semakin selektif memenuhi keinginannya. Serta, penerapan stock market behavior sudah dilakukan dengan baik menunjukkan bahwa UMKM Kota Bandung telah memperhatikan pada strategi harga (pricing) yang diimbangi dengan kualitas produk dan pelayanan. 


\section{Simpulan dan Saran}

Para pelaku UMKM Kota Bandung sebagian besar belum menerapkan teknologi informasi. Namun UMKM Kota Bandung yang telah menerapkan teknologi informasi telah menggunakan media sosial, web sendiri, dan penyedia layanan web dalam menjalankan usahanya.Pelaku UMKM Kota Bandungyang telah menggunakan TI memiliki kesiapan yang sangat baik dalam menerapkan e-commerce. Melihat kesiapan tersebut menunjukkan bahwa para pelaku UMKM Kota Bandung dapat mengembangkan usaha ke arah industri kreatif digital dengan baik. Bagi penelitian berikutnya perlu dikaji faktor pemicu keberhasilan industri kreatif di Kota Bandung.

\section{Daftar Pustaka}

Aulia, D. 2014. Apa itu Masyarakat ASEAN.

https://daninformen.wordpress.co

m/ 2014/09/13/apa-itu-

masyarakat-ekonomi-asean/

Inay.2015. Kesiapan Mahasiswa Jadikan

MEA sebagai

Pencerahan.[Universal Post

Manager] plugin from

www.ProfProjects.com

Koran Sindo.Mei, 2014.Bagaimana Kesiapan SDM Indonesia Menghadapi MEA.

Prasetyo, B. 2014.Menilik Kesiapan Dunia Ketenagakerjaan Indonesia Menghadapi MEA.Jurnal Rechts Vinding.

Rangkuti, F (2008). Strategi Promosi yang Kreatif. Jakarta: PT.Gramedia Pustaka Utama.

Sugiama, Gima, A. 2008. Metode Rise Bisnis dan Manajemen. Bandung: Gunadarma Intimarta.

Sugiyono. 2007. Metode Penelitian Bisnis. Cetakan Kesepuluh. Bandung: Alfabeta.
Yushita, A. N. Kesadaran Kewajiban Perpajakan pada Sektor Usaha Kecil dan Menengah.Working paper.UNY.

http://bisnisukm.com/pentingnya-strategipemasaran-untuk-ukm.html 